\title{
Sciendo
}

DOI: 10.2478/RAE-2019-0033 Review of Artistic Education no. 182019 293-299

\section{ACTIVE LEARNING AND DEVELOPMENT OF DESIGN THINKING ABILITY AT STUDENTS}

\author{
Oana Jitaru ${ }^{310}$
}

\begin{abstract}
The paper analyzes paradigms that highlight the role of active teaching and active learning methods in developing the skills for the professional and social life of the students. The first chapter of the paper argues the need to develop social and creative abilities that lead students to competence in design thinking. Successful response of the student to the demands of professional and social life requires skills like empathy, assertiveness, cooperation, problem solving, implementation of innovative solutions. Ability of design thinking involves a divergent thinking, ability to autonomously design their own strategies in relation to personal development needs, self-assertion and prosocial project development. The training of these skills is possible if the educational environment is one that offers stimulating techniques, adequately prepared human resources, social training contexts. Interactive teaching enables the student to act independently, to be capable of selfmanagement and personal development. The proactive creativity of teachers facilitates active learning methods which will lead to students developing empathy, assertiveness and competence in design thinking.
\end{abstract}

Key words: design thinking ability, active learning, assertivity, empathy, social competence

\section{Student facing the requests of the contemporary social environment.} Ability of "design thinking"

Adapting to the contemporary world involves the individuals' social and civic abilities, which allow them to integrate in complex social context, abilities to value their own abilities at level of competences in a professional field that could assure them an optimum living and, more than that, stimulates the experimentation and discovery in the field of personal growth, creativity in private life, self-actualisation, spiritual evolution. Tony Wagner $(2014,27)$ summarises the results of an important study about innovation in 2011, appreciating the fact that innovation in our times values especially people's creativity expressed at various levels of the social life, and that the biggest innovations in the 21 st century will be those that respond to human needs, adapted to protecting the environment. The author describes new skills that today's pupils and students need for their career, sustained education and citizenship in the world ever challenging. He identifies seven major requests and calls them skills necessary for survival. These are: critical thinking and problemsolving; collaborating across networks and leading by influence; agility and adaptability; accessing and analysing information; effective oral and written communication; curiosity and imagination.

\footnotetext{
${ }^{310}$ Lecturer PhD., "Gheorghe Asachi" Technical University from Iaşi, Romania, email: oana_gavril2002 @yahoo.com
} 
To these, the author adds perseverance, availability to experiment and take calculated risks, tolerate failure and the ability to "think in a projective way" (design thinking), together with critical thinking. In an article published in Harvard Business Review, Tim Brown described the five characteristics of the type of design thinker:

1. Empathy, capacity to imagine the world from multiple perspectives and to place the world on the first place;

2. Integrative thinking, the ability to see all the aspects of a problem, as well as possible revolutionary solutions;

3. Optimism assures the belief that, even when difficult, problems will find their solutions;

4. Experimentalism, process of trials, failures and corrections that analyse the problems and solutions in new and creative ways;

5. Collaborativity, the enthusiast interdisciplinary collaborator.

In conclusion, this design thinker is a specialist able to innovate in their field of expertise, this innovator's "DNA" having as central nucleus

- Empathy and curiosity, weaved in a structure that allows man to listen to, observe, ask questions and reach a more profound understanding of the others;

- The integrative thinking supposes mastering a field of expertise, being creative and motivated; it supposed crossing borders, making associations and syntheses;

- Collaboration and activity in a network is based on social abilities of communication, assertiveness and tolerance.

- Action and experimentation suppose capacity of initiative, strategic thinking and self-confidence that support a process of alternate trial, failure, solution and success.

As for the innovator's formation, as education challenge, the author draws attention on the fact that the traditional approach of the learning process involves a transfer of information based on memorisation, exponential growth of the quantity of information, undermining curiosity, the ability to ask questions and reach beyond theories and facts. The formation of the design thinker would require the capacity to analyse and create new knowledge, filter information and apply it in unusual ways. It seems that we cross a time where "it is less important what you know than what you can do with what you know" (Wagner, 2014, 205). Thus, we can distinguish three stages in the evolution of learning: the first one is based on memorising, on tests with multiple variants of answer, a stage still prevalent; a second stage is learning based on projects, starting with a problem that needs a solution; and the third stage is learning based on design and planning, where problem is not given, but needs to be defined. The third type of learning is based on the development of creative thinking that allows overcoming limits, unusual associations, defining and redefining problems in ambiguous situations, in essence, students are determined to present problems instead of repeating answers. 
The habits necessary for survival define in fact a set of competences that a graduate should accumulate during their formation in order to be able to capitalise maximally the potential they have and obtain economic, social and familial progress. In this set of competences, they have to re-find their creative abilities that develop flexibility, originality, sensitiveness to problems; the social abilities that involve communication, cooperation, empathy, assertiveness, selfintroduction, self-esteem, a set of abilities that give man the belief that they can master their life, can produce impactful results; abilities to exploit interdisciplinarity, combine in an innovative way different fields of interest exact sciences, art, literature, etc. An important condition to gain these competences is to assure the context where students can prove they master them. A part of the skills mentioned can be assessed, for the didactic profession, in formal and non-formal context, others during the pedagogic practice, and others will be assured by their transfer in student's specific social contexts, and will be underlined in the strategies of self-affirmation and the professional projects and the projects of social innovation that they will implement.

Thomas Friedman, in an interview offered to Tony Wagner (op. cit., 301), states that more important that IQ are the curiosity quotient (CQ) and passion quotient (PQ), which have to be developed and cultivated, giving the student the chance to explore on their own fields of interest and their own expression. We consider that in order to create an appropriate environment to train multiple intelligences, emotionality, curiosity, passion, the student has to build, at first, a positive self-image, high self-esteem, and abilities to communicate assertively to express themselves empathically and, at the same time, in a firm, unique, independent and innovating way.

Success and triumph as member of society are supported by an effective management of the social, emotional and cognitive abilities, as well as the behaviours adapted to the social requests. Janet Welsh and Karen Bierman (2001, 600) outline social competence through the social, emotional and cognitive abilities, and the behaviours that a person needs for a successful social adaption. For youngsters and adults, social competence integrates a series of enriched abilities and behaviours derived from the individuals' orientation and, their professional actions, as well as their actions and citizens. In outlining the social competence of the young and adult person, theories and research (Argyle, 1998, 74; Hoskins et al., 2008, 12) lead to the acceptation that being socially competent means to be integrated in a network of communication and solid cooperation, affirm oneself as member of the professional group, manage in a constructive way relations and intercultural, community, civic or political situations. Michael Argyle $(1998,74)$ underlined the indispensable correlation between the social and professional competence, through the two dimensions of the social competence: social competence that comprises general ability, and the social professional competence, related to work, the ability to stimulate and make the others gain efficiency in exercising their profession. The author 
mentions a series of social competences necessary in view of establishing and maintaining the relations of support of the adult with family, friends and colleagues. Also, Argyle (1998, 86-87) names another essential field where the social competence of the young and adult person manifests - couple and marriage. Social competence manifests at the young and adult age in the context of the family, the network of friends, the couple relation and marriage, professionally, but also civically. To support this statement, Bryony Hoskins, Ernesto Villalba, Daniel Van Nijlen and Carolyn Barber $(2008,12)$ notice the connection between social and civic competence. If the individual meets, at different stages of their life, opportunities of civic learning, then they will develop as an active citizen. In other words, the social competence exerted in a familial, educational, professional context will support the adult's competent manifestation and the role of active citizen. Developing the student's creativity, their ability to design thinking, abilities of communication, and social and civic affirmation will assure them a set of competences necessary for the professional and social life. The individual can manifest, thus, as an autonomous personality, civically involved and innovating in valuing and enriching the social environment where they live.

\section{Active Learning - a Result of the Professor-Student Collaboration}

Active learning that implies that education makes available for the pupil/student an interactive and creative environment that allows them to became aware of the level of their own knowledge and the diversity of means of knowledge, ask questions, listen, discuss, solve, apply, research, discover, etc. As shown in the literature (Bonwell and Eison, 1991, Prince, 2004, Cerghit, 2006; Bocoș 2013), active learning has several defining characteristics. It is a type of learning based on profound individual involvement - intellectual, psychomotor, affective and volitional - of the subject of learning in acquiring knowledge actively and creatively, formation and development the abilities and competences. Learning focused on the student is superior to passive learning, focused on the professor. Students acquire knowledge and abilities through activities that allow them to exert and reflect, not though those that require looking at and listening to others who tell them about how to do something (Felder, Woods, Stice and Rugarcia, 2000, 9). The passive methods of teaching promote memorisation on short term, while the active approach of the didactic interaction promotes storing in their memory the information on a long term, understanding, stimulating the abilities to solve problems, motivation to learn and interest in in-depth studies.

Active and interactive learning is based on an asymmetric/dissymmetric educational relation where the student himself has the role of "pedagogic regulator" (Bocos, 2013, 86), and the professor has the role of organiser and guide of the process of learning carried out by the student. The interactive context built by the professor and the active and stimulating methodology used, 
help the pupil/student accompany learning with positive emotional states of pleasure, trust in their own potential, wish for knowledge, tendency to selfactualisation. The individual who learns actively and interactively is their own initiator and organiser of the learning experiences, the manager of their own resources, able to reorganise to reorganise permanently their own acquisitions, in a systemic manner. Active learning implies that the subject of learning develops activities and registers significant acquisitions, but at the same time they are able of meta-cognition, which means that they think and analyse the mechanisms of their own approaches to understanding and learning. Thus, students become able to monitor and self-regulate their learning, debate critically, assess, improve, design customised learning projects, assume responsibility for the personal educations objectives formulated, get involved autonomously in learning and formation (Chi, M.T.H., Kang, S. and Yaghmourian, D.L., 2017).

Interactive instruction operates with methods, techniques and educational means focused on the pupil/student's activity of learning. Thus, we can talk about a pedagogy focused on pupil/student, who becomes the actor in the educative act, in elaborating regulations and rules regarding the work rhythm, learning style, grid for reading reality determined by particularities of personality, abilities for adapting and social affirmation. Active-learning instructors are aware of best practices related to students motivation (Auerbach, Higgins, Brickman and Andrews, 2018). The pupil/student is supported to develop autonomy, a pedagogic concept with multiple educative dimensions, correlated with activation, freedom of choice, responsibility, critical thinking, meta-cognition. The concept of "autonomy" comes from Greek, having the meaning of "to make your own rule." To be autonomous means that the individual is not somebody else's subordinate, and they are able to follow their own inner standards. The independent young adult is the one who consolidates their individual identity placing on stage personal decisions regarding their own life and assuming responsibility for those decisions. Feeling good with yourself, being able to follow your own wishes is an essential sign of autonomy (Ruppert, $2015,316)$. In order to find your own way, it is necessary to have a firm and healthy will that supposes delimitation from what others want from you and the clarification of what you can and creates an inner energetic flux experienced as motivation and passion.

\section{Conclusions}

Today's pupils and students need new skills to develop their career, to adapt optimally to social life, and to became prosocial and civic personalities in an ever challenging world. Seven major skills for survival are requested: critical thinking and problem-solving; collaborating across networks and leading by influence; agility and adaptability; accessing and analysing information; effective oral and written communication; curiosity and imagination. In this 
context, design thinking is a complex skill that has in the core the following components: empathy, integrative thinking, optimism, experimentalism, colaborativity.

Students' formation in an environment characterised by trust, respect, educational values integrated to the social context and the recognition of each person's meaningfulness are essential in developing creative, social and civic the competences. Also important are learning in the context of real life focused on problem and context. Developing the competence of autonomous learning can increase the students' ability to extract meaning and knowledge from the personal story and society, and the abilities of critical and creative thinking can improve the communication abilities and the academic results, in general.

Active learning is the one that assures an environment in which the student manifests himself independently, learns to become assertive and promote his / her own rights and abilities, practices creativity in problem solving and in project development. The ability of disign thinking can only be developed in an active and interactive educational environment where the teacher is a promoter of innovative thinking and facilitates student experiences of professional and social development.

\section{References}

Argyle, M. (1998). Social Skills. În S. Moscovici (coord.). Social Psychology of Relationships With Other. Iassy: Polirom Publishing. (pp. 74-90).

Auerbach, A.J., Higgins, M., Brickman, P. and Andrews T.C. (2018). Teacher Knowledge for Active-Learning Instruction: Expert-Novice Comparison Reveals Differences., Life Sciences Education, 17 (1): 12, doi: 10.1187/cbe.1707-0149.

Bocoș, M.D. (2013). Interactive Instruction. Iassy: Polirom Publishing. Bonwell, C.C. și Eison, J.A. (1991). Active Learning: Creating Excitement in the Classroom. ASHE-ERIC Higher Education Report No.1. Washington, DC: George Washington University.

Cerghit, I. (2006). Teaching Methods. Iassy: Polirom Publishing.

Chi, M.T.H., Kang, S. and Yaghmourian, D.L. (2017). Why students learn more from dialogue - than monologue-videos: Analysis of peer interactions. Journal of the Learning Sciences, (1), 10-50.

Hoskins, B.L. și Crick, R.D. (2008). Learning to Learn and Civic Competences: different currencies or two sides of the same coin? Luxembourg: Office for Official Publications of the European Communities. 1-22. http://crell.jrc.ec.europa.eu/Publications/CRELL\%20Research\%20Papers/Learni ng\%20to\%20Learn\%20and\%20Civic\%20Competences\%20FINAL\%20final.pdf Hoskins, B.L., Villalba, E., Van Nijlen, D. și Barber, C. (2008). Measuring Civic Competence in Europe: A Composite Indicator IEA Civic Education Study 
1999 for 14 Years Old in School. Luxembourg: Office for Official Publications of the European Communities. (pp. 1-132).

Prince, M.J. (2004). Does Active Learning Work? A Review of the Research, Journal of Engineering Education, 93(3), 223-231.

Rupert, F. (2015). Symbiosis and Autonomy. Bucharest: Three Publishing.

Wagner, T. (2014). Creating Innovators. The Making of Young People Who Will Change the World. Bucharest: Three Publishing.

Welsh, J.A. și Bierman, K.L. (2001). Social competence. În B.R. Strikland (ed). Gale Enciclopedia of Psychology. Detroit: Gale Group. (pp. 597-604). 